\title{
Metabolic engineering and classical selection of the methylotrophic thermotolerant yeast Hansenula polymorpha for improvement of high-temperature xylose alcoholic fermentation
}

Olena O Kurylenko', Justyna Ruchala², Orest B Hryniv ${ }^{1}$, Charles A Abbas ${ }^{3}$, Kostyantyn V Dmytruk ${ }^{1}$ and Andriy A Sibirny ${ }^{1,2^{*}}$

\begin{abstract}
Background: The methylotrophic yeast, Hansenula polymorpha is an industrially important microorganism, and belongs to the best studied yeast species with well-developed tools for molecular research. The complete genome sequence of the strain NCYC495 of H. polymorpha is publicly available. Some of the well-studied strains of H. polymorpha are known to ferment glucose, cellobiose and xylose to ethanol at elevated temperature $\left(45-50^{\circ} \mathrm{C}\right)$ with ethanol yield from xylose significantly lower than that from glucose and cellobiose. Increased yield of ethanol from xylose was demonstrated following directed metabolic changes but, still the final ethanol concentration achieved is well below what is considered feasible for economic recovery by distillation.

Results: In this work, we describe the construction of strains of $H$. polymorpha with increased ethanol production from xylose using an ethanol-non-utilizing strain $\left(2 \mathrm{EthOH}{ }^{-}\right)$as the host. The transformants derived from $2 \mathrm{EthOH} \mathrm{H}^{-}$overexpressing modified xylose reductase $(X Y L 1 \mathrm{~m})$ and native xylitol dehydrogenase (XYL2) were isolated. These transformants produced 1.5 -fold more ethanol from xylose than the original host strain. The additional overexpression of XYL3 gene coding for xylulokinase, resulted in further 2.3-fold improvement in ethanol production with no measurable xylitol formed during xylose fermentation. The best ethanol producing strain obtained by metabolic engineering approaches was subjected to selection for resistance to the known inhibitor of glycolysis, the anticancer drug 3-bromopyruvate. The best mutant selected had an ethanol yield of $0.3 \mathrm{~g} / \mathrm{g}$ xylose and produced up to $9.8 \mathrm{~g}$ of ethanol/l during xylose alcoholic fermentation at $45^{\circ} \mathrm{C}$ without correction for ethanol evaporation.
\end{abstract}

Conclusions: Our results indicate that xylose conversion to ethanol at elevated temperature can be significantly improved in H. polymorpha by combining methods of metabolic engineering and classical selection.

Keywords: 3-Bromopyruvate, High-temperature fermentation, Xylose, Fuel ethanol, Hansenula polymorpha

\footnotetext{
* Correspondence: sibirny@cellbiol.lviv.ua

'Department of Molecular Genetics and Biotechnology, Institute of Cell

Biology, National Academy of Sciences of Ukraine, Drahomanov Street, 14/16,

Lviv 79005, Ukraine

${ }^{2}$ Department of Biotechnology and Microbiology, University of Rzeszow,

Zelwerowicza 4, Rzeszow 35-601, Poland

Full list of author information is available at the end of the article
} 


\section{Background}

The production of bioethanol from renewable feedstocks represents the largest industrial fermentation process with over 85.2 billion liters of fuel ethanol produced in 2012 [1]. Currently ethanol is produced from traditional feedstocks (corn starch and sugarcane) and is known as $1^{\text {st }}$ generation biofuel. Due to increased production of ethanol and the uses of these feedstocks for food and feed applications, no significant growth in $1^{\text {st }}$ generation ethanol production is possible. This is the main reason for continued interest in the development of cost effective technology for the production of the $2^{\text {nd }}$ generation bioethanol from lignocellulosics. These feedstocks primarily consist of commodity crop processing residues, field residues and wood waste processing residues. Fast growing energy crops such as switch grass, miscanthus and trees that can be cultivated in poor or marginal soils have also been touted as possible sources of lignocellulosic feedstocks. In spite of the potential availability of lower cost lignocellulosic feedstocks, the complex structure of these has hindered the development of a cost effective technologies for $2^{\text {nd }}$ generation bioethanol production. The major problems which prevent large scale bioethanol production from lignocellulosics are the absence of: environmentally friendly and cheap technology for lignocellulose pretreatment and hydrolysis and the unavailability of microbial strains which efficiently ferment the major pentose sugars of hemicellulose, of which xylose is the most abundant sugar [2-4]. Some of the different approaches used to overcome these bottlenecks are the development of Consolidated Bioprocessing (CBP) for the pretreatment, hydrolysis and fermentation of lignocellulose to ethanol and the use of Simultaneous Saccharification and Fermentation (SSF) process to ferment pretreated lignocellulose [5,6]. In the last process, the pretreated lignocellulose is subjected to enzymatic hydrolysis by cellulases and hemicellulases during the fermentation which converts liberated sugars to ethanol and thus avoids end product inhibition of the enzymes by these sugars. During SSF, microorganisms which efficiently ferment pentose and hexose sugars are utilized [7]. As cellulases and hemicellulases express maximal activities at temperatures in the range $50-60^{\circ} \mathrm{C}$, it is desirable that the microorganisms used for SSF have higher thermotolerance than the currently used industrial ethanologens [8].

There are many promising ethanologenic microorganisms capable of fermenting the major pentose sugar, $x y-$ lose. The list includes natural xylose-fermenting yeasts, such as Pichia (Scheffersomyces) stipitis, Candida shehatae, Pachysolen tannophilus, Spathaspora passalidarum, recombinant yeast Saccharomyces cerevisiae, and several recombinant ethanologenic bacteria such as Escherichia coli, Klebsiella oxytoca, Zymomonas mobilis, several sp of Bacillus and Lactobacillus [3,9-12]. Most of these ethanologens are mesophilic organisms that cannot grow and ferment at temperatures above $40-42^{\circ} \mathrm{C}$. A number of ethanologenic high temperature anaerobic bacteria such as Thermoanaerobacterium saccharolyticum are promising organisms capable of high-temperature xylose fermentation [13]. However, bacteria have some technological disadvantages when compared to yeasts, such as susceptibility to bacteriophage lysis, uncertainty in regulation that hinder the use of their biomass for feed, and some, unlike yeast, have not been in use at industrial scale. With the exception of Kluyveromyces marxianus [14], Hansenula polymorpha, is the most thermotolerant yeast known with growth up to a maximal temperature of $50^{\circ} \mathrm{C}$ [15]. It has been demonstrated that $H$. polymorpha can ferment glucose, cellobiose and xylose [16] and is able to convert glycerol to ethanol [17]. Wild-type strains of this yeast normally ferment xylose up to a maximal temperature of $48^{\circ} \mathrm{C}$, whereas at $50^{\circ} \mathrm{C}$ fermentation is strongly suppressed. Genetic manipulation leading to increase in intracellular trehalose following knock out of acid trehalase gene ATH1 or the overexpression of the heat shock proteins Hsp16 and Hsp104, have been demonstrated to allow normal xylose fermentation at $50^{\circ} \mathrm{C}$ [18]. The ethanol tolerance of $H$. polymorpha can be further increased by the overexpression of the heterologous gene MPR1 [19] or endogenous gene ETT1 [Ishchuk O, Abbas C, Sibirny A, in preparation]. The methylotrophic yeast, $H$. polymorpha is an industrially important microorganism, and belongs to the best studied yeast species with well-developed tools for molecular research [20,21]. The complete genome sequence of the strain NCYC495 of $H$. polymorpha is publicly available [22].

$H$. polymorpha can be a promising organism for both CBP and SSF processes. Recombinant strains of this organism have been engineered which express amylolytic and xylanolytic enzymes and directly ferment starch and xylan to ethanol [23]. Considering SSF process, H. polymorpha belongs to very few thermotolerant yeast species capable of xylose fermenting and could be the organism of choice, however, it is not free from several drawbacks. Most importantly, ethanol yield and productivity from xylose in wild-type strains of $H$. polymorpha are very low. However, these features could be improved by classical selection and metabolic engineering. Three approaches have been used earlier for construction of $H$. polymorpha strains which improved ethanol production from xylose. In one line of investigation, $H$. polymorpha gene XYL1 coding for xylose reductase (XR), two paralogs of xylitol dehydrogenase (XDH) XYL2A and $X Y L 2 B$, were deleted in the strain CBS4732 with the expression of the bacterial gene $x y l A$ from $E$. coli or Streptomyces coelicolor [24]. The corresponding transformants expressed xylose isomerase activity and grew on xylose, but the amount of accumulated ethanol was very low (both transformants and wild-type cells 
accumulated maximally $0.15 \mathrm{~g}$ of ethanol/l). The overexpression of E. coli xylA together with $H$. polymorpha $X Y L 3$ coding for xylulokinase (XK), increased ethanol production, however, maximal ethanol accumulation did not exceed $0.6 \mathrm{~g} / \mathrm{l}$ at $48^{\circ} \mathrm{C}$ [25]. In the second line of investigation, the $H$. polymorpha XR gene was engineered by site specific mutagenesis to reduce affinity toward NADPH using a similar approach developed for Candida tenuis [26]. Consequently, genes coding for modified XR (XYL1m), native XDH (XYL2) and XK (XYL3) were overexpressed in strain CBS4732 which yielded a 2 -fold higher ethanol accumulation in corresponding transformants reaching $1.3 \mathrm{~g}$ of ethanol/l [27]. In third line of investigation, the wild-type $H$. polymorpha strain NCYC495 (currently, the sequenced strain) was selected as the initial host as it was shown to be a more efficient xylose fermenter relative to the strain CBS4732. The $H$. polymorpha mutant $2 \mathrm{EthOH}^{-}$unable to utilize ethanol as a sole carbon source was isolated from strain NCYC495 and characterized by a 3 -fold increase in ethanol accumulation. Subsequently, the gene PDC1 coding for pyruvate decarboxylase (PDC) was cloned and overexpressed in strain $2 \mathrm{EthOH}^{-}$. The best selected transformants from $2 \mathrm{EthOH}^{-}$accumulated $2.5 \mathrm{~g}$ of ethanol/l at $48^{\circ} \mathrm{C}$ [28]. This concentration is still very low and has to be substantially increased before the strain can meet requirements for industrial production using an SSF process.

In the current work, we describe the construction of more efficient $H$. polymorpha high-temperature ethanol producers from xylose. For this, the combination of methods of metabolic engineering and classical selection were applied. Strain $2 \mathrm{EtOH}^{-}$was used for overexpression of $H$. polymopha genes XYL1m, XYL2, XYL3 and $P D C 1$. The best selected transformant was used for the isolation of mutants resistant to the anticancer drug 3bromopyruvate which is known to inhibit glycolysis [29-31]. The best mutant obtained showed a 15 -fold enhancement in ethanol synthesis from xylose when compared to the wild-type strain accumulating up to $10 \mathrm{~g} / \mathrm{l}$ of ethanol at $45^{\circ} \mathrm{C}$.

\section{Results}

Construction of strains overexpressing engineered XR and native $\mathrm{XDH}$

Analysis of our previous data showed that the highest ethanol yield from xylose was achieved using an ethanol-non-utilizing strain that was derived from strain NCYC495. The corresponding mutant $2 \mathrm{EthOH}^{-}$ was characterized by a 3-fold higher ethanol yield on the third day of xylose fermentation, relative to the wild-type strain. The underlying molecular nature of the mutation in the strain $2 \mathrm{EthOH}^{-}$is not known as can be caused by a change in one of the alcohol dehydrogenase isozymes [28]. Recently, it was also shown that overexpression of certain genes in $H$. polymorpha led to an increase in ethanol production from xylose. These changes may result from the cloning of an engineered $X R$ and native $\mathrm{XDH}, \mathrm{XK}$ and PDC (XYL1m, XYL2, XYL3, PDC1) $[25,27,28]$. We hypothesized that introduction of additional copies of these genes into the genome of the mutant strain $2 \mathrm{EthOH}^{-}$could further improve ethanol production during xylose fermentation. For the cooverexpression of genes $X Y L 1 m$ and $X Y L 2$ under control of the strong constitutive promoter of the gene GAP1 encoding glyceraldehyde-3-phosphate dehydrogenase, the plasmid $\mathrm{pX} 1 \mathrm{~m}-\mathrm{Z}-\mathrm{X} 2$ was constructed and used to transform strain $2 \mathrm{EthOH}^{-}$. Selection of transformants was performed on media supplemented with increased concentration of the selective agent zeocin assuming multicopy integration of the plasmid bearing the $Z e o^{R}$ selective marker gene. Transformants were selected on medium with $0.3 \mathrm{~g}$ of zeocin/l. After stabilization via cultivation in non-selective medium for 10-12 generations, the cells were grown in a selective medium and subjected to biochemical analyses. The best obtained transformant $2 \mathrm{EthOH}^{-} / \mathrm{XYL} 1 \mathrm{~m} / \mathrm{XYL} 2$ was characterized by a 1.7 -fold increase in specific activity of XR and a 10fold higher activity of XDH (Table 1). The overexpression of XYL1m and XYL2 genes resulted in a 1.5-fold increase in ethanol production during xylose fermentation in batch culture with limited aeration reaching $3.3 \mathrm{~g} / \mathrm{l}$ of ethanol at $45^{\circ} \mathrm{C}$ with a 1.7 -fold reduction in xylitol production when compared to the parental strain (Table 2, Figure 1).

\section{Selection of strains co-expressing XR and XDH in part with XK and/or PDC}

For further improvement of ethanol production from $\mathrm{xy}$ lose the genes XYL3 or PDC1 were separately or in combination overexpressed in the background of the former strain $2 \mathrm{EthOH}^{-} / \mathrm{XYL1m} / \mathrm{XYL} 2$ using the expression vectors pGLG61/XYL3, pGLG61 + prGAP + PDC1Hp and pGLG61/XYL3/PDC1. The abovementioned plasmids were derived of pGLG61 and contain a weakly expressed bacterial gene $A P H$ encoding aminoglucoside-3-phospho transferase as the dominant marker for geneticin (G418) resistance, and the sequence of the HARS36 (TEL188) as autonomic replicating sequence. Such elements ensure multiple tandem integration of pGLG61 into the $H$. polymorpha telomere regions on a medium containing geneticin [32]. Transformants expressing XYL3 and both XYL3 and $P D C 1$ genes were selected on a medium supplemented with $0.5 \mathrm{~g} / \mathrm{l}$ geneticin while the strains expressing $P D C 1$ were selected on a medium with up to $1.0 \mathrm{~g} / \mathrm{l}$ of this antibiotic. All types of transformants were stabilized. The presence of the corresponding plasmids in the stabilized transformants was confirmed by diagnostic PCR. 
Table 1 XR, XDH, XK, PDC activities of $H$. polymorpha transformants and control strain

\begin{tabular}{|c|c|c|c|c|}
\hline \multirow[t]{2}{*}{ Strain } & \multicolumn{4}{|c|}{ Activity (U/mg protein) } \\
\hline & $\mathrm{XR}$ & $\mathrm{XDH}$ & $\mathrm{XK}$ & PDC \\
\hline $2 \mathrm{EthOH}^{-}$ & $0.041 \pm 0.002$ & $0.11 \pm 0.005$ & $0.10 \pm 0.005$ & $0.26 \pm 0.013$ \\
\hline 2EthOH ${ }^{-} / \mathrm{XYL} 1 \mathrm{~m} / \mathrm{XYL2}$ & $0.069 \pm 0.003$ & $1.12 \pm 0.052$ & $0.12 \pm 0.006$ & $0.32 \pm 0.011$ \\
\hline 2EthOH ${ }^{-} / \mathrm{XYL1m} / \mathrm{XYL2/XYL3}$ & $0.075 \pm 0.004$ & $1.15 \pm 0.057$ & $0.31 \pm 0.012$ & - \\
\hline 2EthOH ${ }^{-} / \mathrm{XYL} 1 \mathrm{~m} / \mathrm{XYL2/PDC1}$ & $0.068 \pm 0.003$ & $1.09 \pm 0.054$ & - & $5.38 \pm 0.091$ \\
\hline 2EthOH ${ }^{-} / \mathrm{XYL1m} / \mathrm{XYL2/XYL3/PDC1}$ & $0.073 \pm 0.004$ & $1.08 \pm 0.053$ & $0.21 \pm 0.009$ & $2.42 \pm 0.089$ \\
\hline 2EthOH ${ }^{-} / \mathrm{XYL} 1 \mathrm{~m} / \mathrm{XYL2/XYL3/BrPA}$ & $0.072 \pm 0.004$ & $1.21 \pm 0.061$ & $0.33 \pm 0.015$ & - \\
\hline
\end{tabular}

-not determined.

The expression of $X Y L 3$ gene in the background of $2 \mathrm{EthOH}^{-} / \mathrm{XYL1m} / \mathrm{XYL2}$ resulted in up to 2.6-fold increase in the specific activity of $\mathrm{XK}$ in selected transformant $2 \mathrm{EthOH}^{-} / \mathrm{XYL1m} / \mathrm{XYL2} / \mathrm{XYL3}$ when compared to the parental strain. The recombinant strain $2 \mathrm{EthOH}^{-} / \mathrm{XYL1m} /$ XYL2/XYL3/PDC1 co-expressing XYL3 and PDC1 genes was shown to have 1.8- and 7.6-fold enhancement of XK and PDC activity when compared to the initial strain. The specific activity of the enzyme PDC in strain 2EthOH ${ }^{-} / \mathrm{XYL1m} / \mathrm{XYL} 2 / \mathrm{PDC} 1$ was 18 -fold increased when compared to strain $2 \mathrm{EthOH}^{-} / \mathrm{XYL1m} / \mathrm{XYL} 2$ (Table 1). Such remarkable increase in PDC activity can only be explained by the multicopy integration of the plasmid pGLG61 + prGAP + PDC1Hp into the engineered strain $2 \mathrm{EthOH}^{-} / \mathrm{XYL1m} / \mathrm{XYL} 2 / \mathrm{PDC} 1$ obtained following selection on the medium supplemented with $1 \mathrm{~g}$ of geneticin/l. All other obtained strains harboring additional copies of XYL3 or/and PDC1 gene, were characterized by identical specific activity of XR and XDH (Table 1). Results of ethanol production at the third day of xylose fermentation at $45^{\circ} \mathrm{C}$ by the constructed strains are shown in Table 2. The highest ethanol production was observed for strain $2 \mathrm{EthOH}^{-} / \mathrm{XYL1m} / \mathrm{XYL} 2 / \mathrm{XYL3}$. Such a strain showed a 2.3-fold improvement in ethanol production relative to the parental strain $2 \mathrm{EthOH}^{-} / \mathrm{XYL1m} /$ XYL2. Strains 2EthOH ${ }^{-} / \mathrm{XYL1m} / \mathrm{XYL} 2 / \mathrm{PDC} 1$ and 2EthOH ${ }^{-} / \mathrm{XYL1m/XYL2/XYL3/PDC1,} \mathrm{synthesized} \mathrm{ap-}$ proximately 1.5 -fold higher amounts of ethanol than that of parental strain. On the $3^{\text {rd }}$ day of xylose fermentation, the best selected strains expressing singly $X Y L 3, P D C 1$ or a combination of these two genes in the background of strain $2 \mathrm{EthOH}^{-} / \mathrm{XYL1m} / \mathrm{XYL2}$, accumulated $7.44 \mathrm{~g} / \mathrm{l}, 4.7 \mathrm{~g} / \mathrm{l}$ and $5.0 \mathrm{~g} / \mathrm{l}$ of ethanol, respectively (Table 2). Thus, the expression of the PDC1 gene in the strain co-expressing all three genes $X Y L 1 m$, $X Y L 2, X Y L 3$ involved in the initial stages of xylose catabolism had no positive effect on ethanol production, though overexpression of PDC1 alone in the background of $2 \mathrm{EthOH}^{-} / \mathrm{XYL1m} / \mathrm{XYL} 2$ strain is beneficial for ethanol synthesis. The impact of XYL3 gene on ethanol production during xylose fermentation is more significant as compared to PDC1 gene, as overexpression of the XYL3 gene resulted in reduced xylitol accumulation during alcoholic fermentation of xylose. The strain $2 \mathrm{EthOH}^{-} / \mathrm{XYL1m} / \mathrm{XYL} 2$ produced $8.5 \mathrm{~g}$ of xylitol / 1 with xylitol yield of $0.29 \mathrm{~g} / \mathrm{g}$ from consumed $\mathrm{xy}-$ lose (Table 2, Figure 1). Expression of gene XYL3 resulted in a significant reduction of xylitol synthesis to zero. By comparison, the overexpression of PDC1 had no influence on xylitol accumulation. The expression of PDC1 in combination with $X Y L 3$, reduced xylitol yield to $0.04 \mathrm{~g} / \mathrm{g}$ caused by an increased activity of XK (Table 1 ). The difference between xylitol production of strains 2EthOH ${ }^{-} / \mathrm{XYL1m} / \mathrm{XYL} 2 / \mathrm{XYL} 3$ and 2EthOH ${ }^{-} / \mathrm{XYL1m} /$ XYL2/XYL3/PDC1 can be explained by the alteration in the specific activity of this enzyme. The activity of XK of strain $2 \mathrm{EthOH}^{-} / \mathrm{XYL1m} / \mathrm{XYL} 2 / \mathrm{XYL} 3$ was 1.5 -fold higher than that of strain $2 \mathrm{EthOH}^{-} / \mathrm{XYL} 1 \mathrm{~m} / \mathrm{XYL} 2 /$ $\mathrm{XYL3/PDC1}$ and this correlated with an increase in copy number of XYL3 gene in the genomes of both strains (Table 1). This demonstates that sufficient activity of XK is necessary for the reduction of xylitol formation during xylose alcoholic fermentation. If the level of $\mathrm{XK}$ is not high enough for complete direction of xylulose to xylulose-5-phosphate, xylulose can be reduced back to xylitol via the reverse reaction catalyzed by $\mathrm{XDH}[33,34]$.

Thus, the overexpression of three enzymes involved in the initial stages of xylose catabolism, modified $\mathrm{XR}$, native $\mathrm{XDH}$ and $\mathrm{XK}$, in the background of an ethanol-non-utilizing mutant $2 \mathrm{EthOH}^{-}$, significantly improved ethanol yield from xylose $(0.25 \mathrm{~g} / \mathrm{g}$ xylose relative to $0.08 \mathrm{~g} / \mathrm{g}$ xylose in the mutant $2 \mathrm{EthOH}^{-}$ after 3 days of xylose fermentation at $45^{\circ} \mathrm{C}$ ), ethanol specific production rate $(0.059 \mathrm{~g} / \mathrm{g}$ biomass $/ \mathrm{h}$ versus $0.017 \mathrm{~g} / \mathrm{g}$ biomass $/ \mathrm{h}$ for parental strain) and ethanol productivity $(0.14 \mathrm{~g} / \mathrm{l} / \mathrm{h}$ versus $0.04 \mathrm{~g} / \mathrm{l} / \mathrm{h}$ for initial strain). In spite of the improvements made to xylose alcoholic fermentation, these are not adequate for a profitable SSF process. Additional production of ethanol from xylose was attempted using the best strain isolated via metabolic engineering approaches and subjected to further strain selection by classical approaches. 
Table 2 Ethanol productivity, ethanol and xylitol yield of $H$. polymorpha transformants and control strain

\begin{tabular}{|c|c|c|c|c|c|c|}
\hline Strain & Ethanol (g/l) & Ethanol yield (g/g consumed xylose) & $\begin{array}{l}\text { Ethanol specific production } \\
\text { rate }(\mathrm{g} / \mathrm{g} \text { biomass } / \mathrm{h})\end{array}$ & Ethanol productivity $(\mathrm{g} / \mathrm{l} / \mathrm{h})$ & Xylitol (g/l) & $\begin{array}{l}\text { Xylitol yield } \\
\text { (g/g consumed xylose) }\end{array}$ \\
\hline 2EthOH ${ }^{-}$ & $2.054 \pm 0.103$ & $0.080 \pm 0.004$ & $0.017 \pm 0.001$ & $0.043 \pm 0.002$ & $15.657 \pm 0.078$ & $0.6074 \pm 0.035$ \\
\hline 2EthOH ${ }^{-} / \mathrm{XYL} 1 \mathrm{~m} / \mathrm{XYL2}$ & $3.285 \pm 0.164$ & $0.113 \pm 0.007$ & $0.034 \pm 0.002$ & $0.083 \pm 0.004$ & $8.458 \pm 0.042$ & $0.2912 \pm 0.019$ \\
\hline 2EthOH ${ }^{-} / \mathrm{XYL} 1 \mathrm{~m} / \mathrm{XYL2} / \mathrm{XYL3}$ & $7.441 \pm 0.371$ & $0.253 \pm 0.031$ & $0.059 \pm 0.003$ & $0.142 \pm 0.007$ & 0 & 0 \\
\hline 2EthOH $/$ XYL1m/XYL2/PDC1 & $4.732 \pm 0.235$ & $0.121 \pm 0.005$ & $0.040 \pm 0.002$ & $0.094 \pm 0.005$ & $6.751 \pm 0.031$ & $0.241 \pm 0.015$ \\
\hline 2EthOH ${ }^{-} / \mathrm{XYL} 1 \mathrm{~m} / \mathrm{XYL} 2 / \mathrm{XYL3/PDC1}$ & $5.043 \pm 0.249$ & $0.163 \pm 0.009$ & $0.042 \pm 0.002$ & $0.105 \pm 0.005$ & $1.104 \pm 0.012$ & $0.036 \pm 0.005$ \\
\hline 2EthOH'/XYL1m/XYL2/XYL3/BrPA & $9.817 \pm 0.411$ & $0.300 \pm 0.011$ & $0.077 \pm 0.004$ & $0.180 \pm 0.009$ & 0 & 0 \\
\hline
\end{tabular}

The data are based on 7 independent replicate cultivations and \pm values represent standard deviations. 


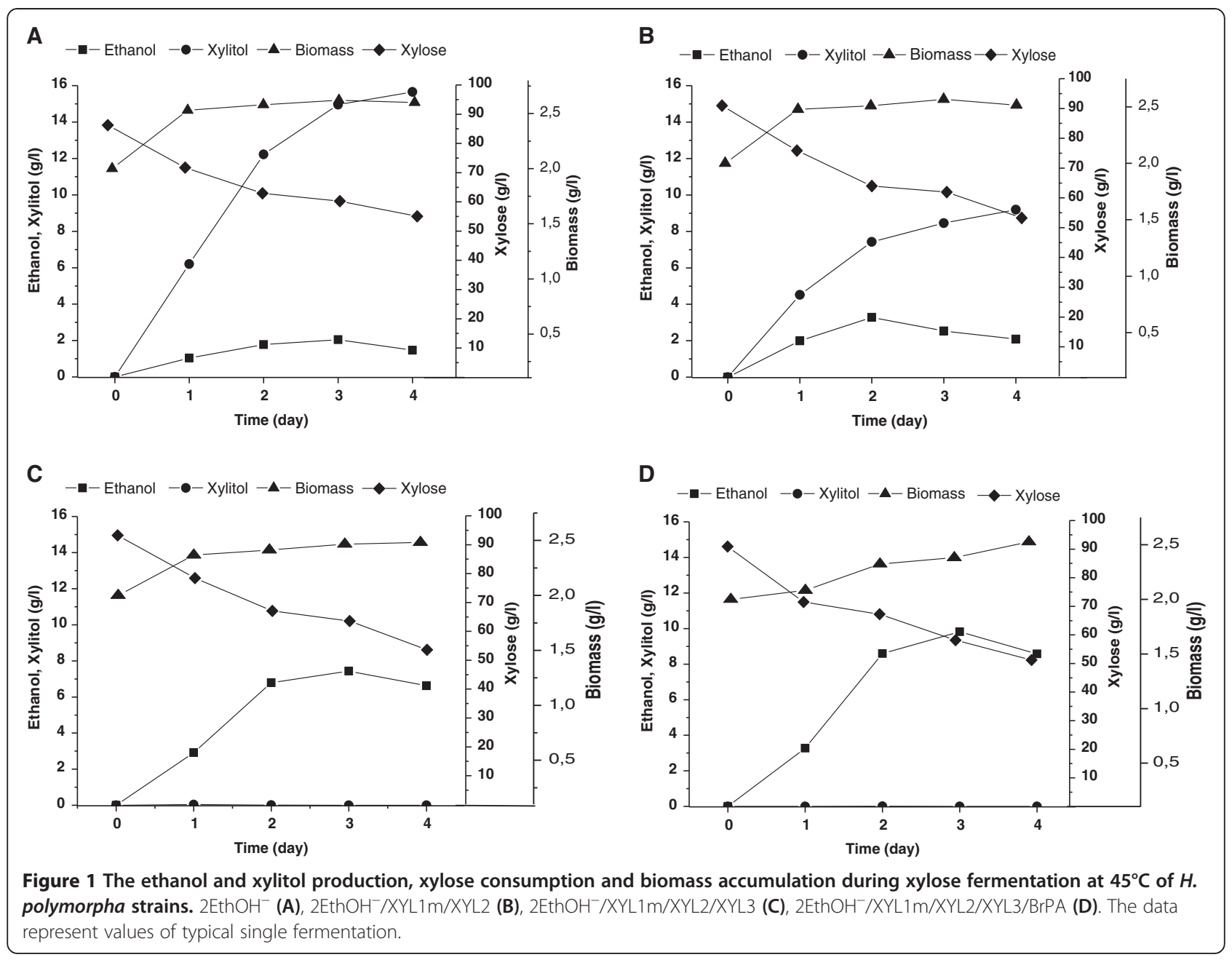

Isolation and characterization of the ethanol overproducing strains resistant to anticancer drug 3-bromopyruvate

3-Bromopyruvate (3-BrPA) has been known for some time as a promising anticancer drug. It is well documented that this compound causes ATP depletion which induce cell death as a result of blocking of glycolysis by the inhibition of the glycolytic enzymes, hexokinase II, glyceraldehyde-3phosphate dehydrogenase and 3-phosphoglycerate kinase. In addition to glycolytic enzymes, 3-BrPA has been shown to have other targets of action [29]. We hypothesized that yeast mutants resistant to 3-BrPA can have mutation in regulatory or structural glycolytic genes leading to increased glycolytic flux and as a result elevated amount of synthesized ethanol during fermentation. In our experiments, the best ethanol-producing strain 2EthOH ${ }^{-}$/XYL1m/XYL2/XYL3 co-overexpressing XYL1m, $X Y L 2$ and $X Y L 3$ genes, was used as target for further selection and improvement. Mutants resistant to 3-BrPA were isolated on solid mineral medium containing xylose as the sole carbon source and supplemented with
$0.11 \mathrm{mM}$ 3-BrPA. Around 150 mutants resistant to 3BrPA were selected and evaluated for the ethanol production during xylose fermentation. The 110 selected mutants possessed increased ethanol production as compared to the parental strain. In other words, approximately $70 \%$ of 3-BrPA-resistant mutants isolated displayed increase in ethanol synthesis during xylose fermentation. The average ethanol yield was increased on $10-20 \%$ as compared to the parental strain. Biochemical characteristics and ethanol production of the best selected mutant $2 \mathrm{EthOH}^{-} / \mathrm{XYL1m} / \mathrm{XYL} 2 / \mathrm{XYL} 3 / \mathrm{BrPA}$ is presented in Table 1. The 2EthOH ${ }^{-} / \mathrm{XYL1m} / \mathrm{XYL2/XYL3/}$ BrPA mutant was characterized by approximately 1.3fold improvement in the ethanol yield as compared to 2 EthOH ${ }^{-} / \mathrm{XYL} 1 \mathrm{~m} / \mathrm{XYL} 2 / \mathrm{XYL} 3$ strain reaching $0.3 \mathrm{~g} / \mathrm{g}$ xylose. This 3-BrPA-resistant mutant had no measurable changes in the specific activities of XR, XDH and $\mathrm{XK}$, as well as in xylitol production relative to the parental strain 2EthOH ${ }^{-}$/XYL1m/XYL2/XYL3 (Table 1).

Representative profiles of ethanol synthesis, biomass accumulation, xylose consumption and xylitol formation for 
the strains $2 \mathrm{EthOH}^{-}, 2 \mathrm{EthOH}^{-} / \mathrm{XYL} 1 \mathrm{~m} / \mathrm{XYL} 2,2 \mathrm{EthOH}$ - XYL1m/XYL2/XYL3 and 2EthOH ${ }^{-} / \mathrm{XYL1m/XYL2/}$ XYL3/BrPA are shown in Figure 1. The consumption of xylose by constructed strains as well as by the initial parental $2 \mathrm{EthOH}^{-}$strain during fermentation was incomplete, suggesting that xylose uptake could be a serious bottleneck leading to inefficient xylose conversion to ethanol and this presents another potential target for further improvement of ethanol production from xylose.

The best obtained 2EthOH ${ }^{-} / \mathrm{XYL} 1 \mathrm{~m} / \mathrm{XYL} / \mathrm{XYL3} / \mathrm{BrPA}$ mutant accumulated $9.8 \mathrm{~g} / \mathrm{l}$ of ethanol after 3 days of fermentation. The synthesized ethanol concentration was corrected for evaporation at high temperature xylose fermentation experiments. It was found that in model experiments when ethanol at fixed concentrations was shaken in fermentation medium under fermentation conditions, approximately $50 \%$ of it was evaporated at $45^{\circ} \mathrm{C}$ in 3 days of incubation (data not shown). Correction for ethanol evaporation gives the calculated amounts of accumulated ethanol as approximately $20 \mathrm{~g} / \mathrm{l}$ on the $3^{\text {rd }}$ day of xylose fermentation at $45^{\circ} \mathrm{C}$. The strain $2 \mathrm{EthOH}^{-} / \mathrm{XYL1m/XYL2/XYL3/BrPA}$, similarly to the parental strain $2 \mathrm{EthOH}^{-} / \mathrm{XYL} 1 \mathrm{~m} / \mathrm{XYL} 2 /$ XYL3, did not accumulate xylitol in the medium.

\section{Discussion}

H. polymorpha belongs to the best studied yeast species with well-developed tools for molecular research. It is used commercially for production of recombinant vaccines, interferons, insulin, enzymes and other products $[21,22]$. Its ability to ferment xylose to ethanol at elevated temperature is known for 10 years; however, ethanol yield and productivity are very low. At the same time, it rather efficiently converts glucose, cellobiose and glycerol to ethanol $[17,18]$. Several metabolic engineering approaches have been successfully developed to improve ethanol production from xylose in $H$. polymorpha, however, ethanol production remained quite low $[24,25,27,28]$. In the current work, we decided to combine several developed earlier approaches of metabolic engineering with classical selection for ethanol overproducing strain using selection for antimetabolite resistance. We demonstrated that there is a positive cumulative effect for the overexpression of engineered $\mathrm{XR}$ and native $\mathrm{XDH}$ and $\mathrm{XK}$ on ethanol production from xylose. Additional overexpression of PDC1 gene coding for PDC did not lead to further improvement of ethanol synthesis from xylose, though overexpression of $P D C 1$ in the background of $X Y L 1 m$ and $X Y L 2$ overexpressed strain increased ethanol production. The impact of XK on ethanol production during xylose alcoholic fermentation is more pronounced when compared to PDC assuming that PDC does not limit xylose conversion in strain expressing $\mathrm{XR}, \mathrm{XDH}$ and $\mathrm{XK}$. Overexpression of XYL1m, XYL2 and XYL3 in the background of non-identified mutation in the strain $2 \mathrm{EthOH}^{-}$, led to substantial increase in ethanol accumulation during xylose fermentation $\left(7.44 \mathrm{~g} / \mathrm{l}\right.$ at $45^{\circ} \mathrm{C}$ relative to $0.6 \mathrm{~g} / \mathrm{l}$ in the wild-type strain NCYC495 and $2.05 \mathrm{~g} / \mathrm{l}$ in the parental strain $2 \mathrm{EthOH}^{-}$).

The method we used for selection of the ethanoloverproducers among 3-BrPA-resistant mutants has been, to our knowledge, demonstrated for the first time to increase ethanol production in yeasts. It is interesting to note that $70 \%$ of 3 -BrPA resistant mutants obtained in this work, produced more ethanol as compared to the parental strain in xylose medium. High percentage of ethanol overproducers provides support for the use of this method for positive selection of ethanol overproducers. In mammalian cells 3-BrPA has multiple targets of action [29-31]. It would be important to identify targets of action of this inhibitor in yeast cells and gene(s) which mutations lead to 3-BrPA resistance and ethanol overproduction. We also have found that selection of 3-BrPA-resistant mutants can be successfully used for the isolation of ethanoloverproducing strains in other yeast species, including S. cerevisiae (unpublished observation). The exact molecular events underlying 3-BrPA resistance in mutants of $S$. cerevisiae and $H$. polymorpha will be described from another separate study [Hryniv, O., Dmytruk, K., Sibirny, A., in preparation].

Thus, in this work we were able to increase accumulation of ethanol from xylose to $10 \mathrm{~g} / \mathrm{l}$ relative to $0.6 \mathrm{~g} / \mathrm{l}$ in the wild-type strain, or more than 15 times by combining the approaches of metabolic engineering and classical selection. The maximal observed level of ethanol produced from xylose by the best isolated strains (near $10 \mathrm{~g} / \mathrm{l}$ at $45^{\circ} \mathrm{C}$ results in an ethanol yield of $0.3 \mathrm{~g} / \mathrm{g}$ from xylose). These results make $H$. polymorpha close to known promising organisms for the use in SSF process. Still this ethanol concentration is lower than ethanol production in mesophilic xylose fermenting organisms such as P. stipitis $(0.35-0.44 \mathrm{~g} / \mathrm{g}$ xylose) and $S$. passalidarum ( $0.42 \mathrm{~g} / \mathrm{g}$ xylose), but similar to the best engineered strain of thermotolerant yeast $K$. marxianus $(0.31 \mathrm{~g} / \mathrm{g}$ xylose under anaerobic conditions at $\left.45^{\circ} \mathrm{C}\right)[12,35,36]$. However, the ethanol productivity in the best $H$. polymorpha isolated strain is much higher when compared to the best engineered strain of $K$. marxianus $(0.179 \mathrm{~g} / \mathrm{l} / \mathrm{h}$ versus $0.054 \mathrm{~g} / \mathrm{l} / \mathrm{h}$ at $45^{\circ} \mathrm{C}$ ). To be industrially feasible, ethanol yield in $H$. polymorpha has to be further increased to be close to the theoretical maximum. We are currently using other targets for metabolic engineering (e.g. xylose transport, pentose phosphate pathway). This we hope can lead to further increase in ethanol yield from xylose during high-temperature alcoholic fermentation of this promising organism. 
Table 3 Yeast strains and plasmids used in this study

\begin{tabular}{|c|c|c|}
\hline Strains & Genotype & References \\
\hline 2EthOH ${ }^{-}$ & leu2 & Ishchuk et al., 2008 [28] \\
\hline 2EthOH $\mathrm{H}^{-} \mathrm{XYL1m/XYL2}$ & pX1M-Z-X2 (GAPp-XYL1mod-AOXt, GAPp-XYL2-XYL2t) & This study \\
\hline 2EthOH $\mathrm{OHYL}^{-} \mathrm{m} / \mathrm{XYL2} / \mathrm{XYL3}$ & pX1M-Z-X2 (GAPp-XYL1mod-AOXt, GAPp-XYL2-XYL2t), pGLG61/XYL3 (GAPp-XYL3-AOXt) & This study \\
\hline 2EthOH ${ }^{-} / \mathrm{XYL} 1 \mathrm{~m} / \mathrm{XYL2} / \mathrm{XYL3/BrPA}$ & As above with unfixed mutations caused by selection on 3-BrPA containing medium & This study \\
\hline 2EthOH ${ }^{-} / \mathrm{XYL} 1 \mathrm{~m} / \mathrm{XYL2} / \mathrm{PDC} 1$ & $\begin{array}{l}\text { pX1M-Z-X2 (GAPp-XYL1mod-AOXt, GAPp-XYL2-XYL2t), pGLG61 + prGAP + } \\
\text { PDC1Hp (GAPp-PDC1-AOXt) }\end{array}$ & This study \\
\hline 2EthOH ${ }^{-} / \mathrm{XYL1m} / \mathrm{XYL2/XYL3/PDC1}$ & $\begin{array}{l}\text { pX1M-Z-X2 (GAPp-XYL1mod-AOXt, GAPp-XYL2-XYL2t), pGLG61/XYL3/PDC1 } \\
\text { (GAPp-XYL3-AOXt, GAPp-PDC1-AOXt) }\end{array}$ & This study \\
\hline
\end{tabular}

\section{Conclusions}

Methods of metabolic engineering and classical selection were successfully applied for construction of more efficient $H$. polymorpha ethanol producers from xylose, leading to 15 -fold enhancement in ethanol synthesis from xylose as compared to the wild-type strain.

\section{Materials and methods}

Strains, media, cultivation conditions

Yeast strain $H$. polymorpha $2 \mathrm{EthOH}^{-}$, a UV-induced mutant derived from the parental strain NCYC495 leu1-1, and transformants listed in Table 3 were grown on YPD (10 g/l yeast extract, $10 \mathrm{~g} / \mathrm{l}$ peptone, $20 \mathrm{~g} / \mathrm{l}$ glucose) or mineral medium (6.7 g/l YNB without amino acids, $40 \mathrm{~g} / \mathrm{l}$ xylose or $20 \mathrm{~g} / \mathrm{l}$ glucose) at $37^{\circ} \mathrm{C}$. For the $2 \mathrm{EthOH}^{-}$strain, leucine $(40 \mathrm{mg} / \mathrm{l})$ was added to the medium. For the selection of yeast transformants on YPD, $0.15-0.3 \mathrm{~g} / \mathrm{l}$ of zeocin or $0.5-1.0 \mathrm{~g} / \mathrm{l}$ of geneticin were added. For the isolation of 3-bromopyruvate resistant mutants, a mineral medium containing glucose or xylose as sole carbon sources with 0.05-0.11 mM of selective agent was used.

The E. coli DH5 $\alpha$ strain ( $880 \mathrm{~d} l a c Z \Delta \mathrm{M} 15$, recA1, endA1, gyrA96, thi-1, hsdR17( $\left.\mathrm{r}_{\mathrm{K}}^{-}, \mathrm{m}_{\mathrm{K}}^{+}\right)$, supE44, relA1,

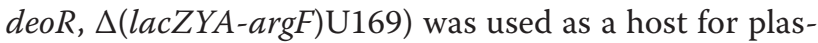
mid propagation. Strain $\mathrm{DH} 5 \alpha$ was grown at $37^{\circ} \mathrm{C}$ in $\mathrm{LB}$ medium as described previously [37]. Transformed $E$. coli cells were maintained on a medium containing $100 \mathrm{mg} / \mathrm{l}$ of ampicillin.

\section{Molecular-biology techniques}

Standard cloning techniques were used as described [37]. Genomic DNA of $H$. polymorpha was isolated using the Wizard ${ }^{\circ}$ Genomic DNA Purification Kit (Promega, Madison, WI, USA). Restriction endonucleases and DNA ligase (Fermentas, Vilnius, Lithuania) were used according to the manufacturer specifications. Plasmid isolation from E. coli was performed with the Wizard ${ }^{\circ}$ Plus SV Minipreps DNA Purification System (Promega, Madison, WI, USA). DNA fragments were separated on a $0.8 \%$ agarose (Fisher Scientific, Fair Lawn, NJ, USA) gel. Isolation of fragments from the gel was carried out with a DNA Gel Extraction Kit (Millipore, Bedford, MA, USA). PCRamplification of the fragments of interest was done with Platinum ${ }^{\circ}$ Taq DNA Polymerase High Fidelity (Invitrogen, Carlsbad, CA, USA) according to the manufacturer specification. PCRs were performed in GeneAmp ${ }^{\circ}$ PCR System 9700 thermocycler (Applied Biosystems, Foster City, CA, USA). Transformation of the yeast $H$. polymorpha by electroporation was carried out as described previously [38].

\section{Plasmid construction}

Plasmid pX1m-Z-X2 was used for overexpression of modified XYL1m gene and native XYL2 gene [27]. Plasmids

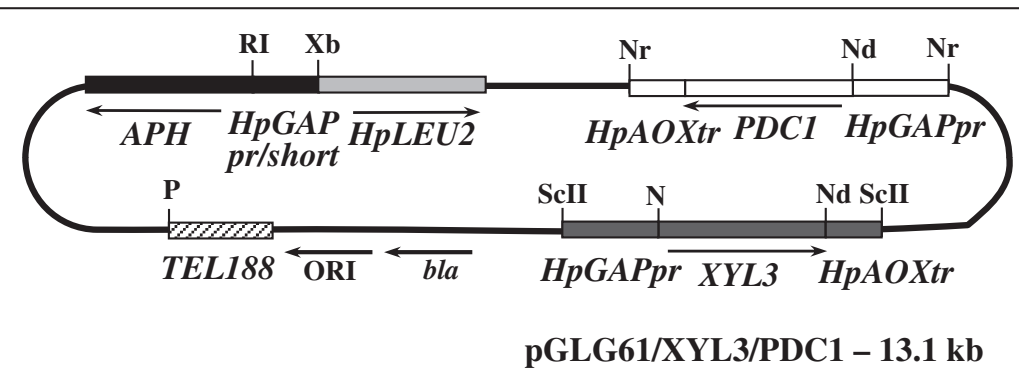

Figure 2 Scheme of the plasmid pGLG61/XYL3/PDC1. Expression cassettes GAPp-XYL3-AOXt and GAPp-PDC1-AOXt are shown as gray and white boxes, respectively. The geneticin resistance gene $(A P H)$, linked to the impaired constitutive gene promoter, encoding glyceraldehyde-3phosphate dehydrogenase (HpGAPpr) and H. polymorpha LEU2 gene are shown as black and light-gray boxes, respectively. The telomeric region (TEL188) as an autonomously replicating sequence is designated with the hatched lines. Origin of replication (ORI) and ampicillin resistance gene (bla) - arrows. Restriction sites: Rl, EcoRl; Xb, Xbal; Scll, Sacll; Nr, Narl; Nd, Ndel; N, Notl; P, Pstl. 
pGLG61/HpXYL3 [25] and pGLG61 + prGAP + PDC1Hp [26] were used for overexpression of XYL3 and PDC1 genes, respectively. For simultaneous overexpression of $X Y L 3$ and $P D C 1$ genes a NarI-restriction fragment containing GAPp-PDC1-AOXt was isolated from the plasmid pGLG61 + prGAP + PDC1Hp and cloned into the NarIlinearized and dephosphorylated vector pGLG61/HpXYL3. The resulting plasmid was named pGLG61/XYL3/PDC1 (Figure 2).

\section{Biochemical methods}

The specific activities of XR, XDH and XK in cell extracts were determined spectrophotometrically as described before [27].

The PDC activity in cell extracts was determined spectrophotometrically according to the methods described earlier [39]. Samples for enzyme activity measurements were taken from the cultures on the third day of xylose fermentation at $45^{\circ} \mathrm{C}$. The enzyme activity was measured directly after the preparation of cell-free extracts as described before [28].

All assay experiments were repeated at least twice.

\section{Selection of 3-bromopyruvate (3-BrPA) resistant mutants}

For isolation of 3-BrPA-resistant mutants solid mineral medium containing glucose or xylose as sole carbon sources with $0.11 \mathrm{mM}$ of selective agent was used. Cell suspension of $2 \mathrm{EthOH}^{-} / \mathrm{XYL1m} / \mathrm{XYL} 2 / \mathrm{XYL} 3$ strain was plated on the 3-BrPA containing medium for final $\mathrm{OD}_{600}=0.1 / \mathrm{ml}$ and incubated at $37^{\circ} \mathrm{C}$ for five days. Single 3-BrPA-resistant colonies were picked up, re-streaked on fresh YNB plates containing $0.11 \mathrm{mM}$ of 3-BrPA and used for fermentation experiments. Selected mutants were stable and possessed resistance to the selective agent even after 6 month growth on agar slant cultures in YPD medium with regular transfer to fresh YPD medium every month.

\section{Analyses}

Cells of transformants were grown in $100 \mathrm{ml}$ of YPX medium (10 g/l yeast extract, $20 \mathrm{~g} / \mathrm{l}$ peptone, $40 \mathrm{~g} / \mathrm{l}$ xylose) in Erlenmeyer flasks (bottle size - $300 \mathrm{ml}$ ) for 2 days and then inoculated into the $40 \mathrm{ml}$ of YNB medium with $90 \mathrm{~g} / \mathrm{l}$ xylose in $100 \mathrm{ml}$ Erlenmeyer flasks. Fermentation was carried out at a temperature of $45^{\circ} \mathrm{C}$ with limited aeration (140 revolutions/min). Concentrations of xylose, xylitol and ethanol from fermentation in medium broth were analyzed by HPLC (PerkinElmer, Series 2000, USA) with an Aminex HPX-87H ion-exchange column (Bio-Rad, Hercules, USA). A mobile phase of $4 \mathrm{mM}$ $\mathrm{H}_{2} \mathrm{SO}_{4}$ was used at a flow rate $0.6 \mathrm{ml} / \mathrm{min}$ and the column temperature was $35^{\circ} \mathrm{C}$. Alternatively concentrations of ethanol in the medium were determined using alcohol oxidase/peroxidase-based enzymatic kit "Alcotest" [40].
For high temperature xylose fermentation experiments, the ethanol concentration was corrected for evaporation. The evaporation coefficient was calculated as a decrease of known concentration of ethanol at $45^{\circ} \mathrm{C}$ temperature.

Experiments were performed at least twice.

\section{Abbreviations}

SSF: Simultaneous saccharification and Fermentation; CBP: Consolidated bioprocessing; XR: Xylose reductase; $\mathrm{XDH}$ : Xylitol dehydrogenase;

XK: Xylulokinase; PDC: Pyruvate decarboxylase; 3-BrPA: 3-Bromopyruvate.

\section{Competing interests}

The authors declare that they have no competing interest.

\section{Authors' contributions}

OOK and JR carried out strains construction, evaluation of enzymes activity, fermentation experiments and co-drafted the manuscript. $\mathrm{OBH}$ participated in cloning and strain construction. CAA commented and approved the manuscript. KVD participated in design of cloning and strain construction, analyzed the date and co-drafted the manuscript. AAS provided guidance and suggestions for experimental design, wrote and edited the manuscript. All authors participated in finalizing the manuscript read and approved the final version of the manuscript.

\section{Acknowledgements}

This work was supported by Science and Technology Center in Ukraine (Grant No. 5505) and National Academy of Science of Ukraine (Grant No. 5-14).

\section{Author details}

${ }^{1}$ Department of Molecular Genetics and Biotechnology, Institute of Cell Biology, National Academy of Sciences of Ukraine, Drahomanov Street, 14/16, Lviv 79005, Ukraine. ${ }^{2}$ Department of Biotechnology and Microbiology, University of Rzeszow, Zelwerowicza 4, Rzeszow 35-601, Poland. ${ }^{3}$ ADM Research, Decatur, IL 62526, USA.

Received: 17 May 2014 Accepted: 12 August 2014

Published: 20 August 2014

\section{References}

1. Renewable fuels association. [http://www.ethanolrfa.org/news/entry/ global-ethanol-production-to-reach-85.2-billion-litres-in-2012]

2. Lin $Y$, Tanaka S: Ethanol fermentation from biomass resources: current state and prospects. App/ Microbiol Biotechnol 2006, 69:627-642.

3. Hahn-Hägerdal B, Galbe M, Gorwa-Grauslund MF, Lidén G, Zacchi G: Bio-ethanol - the fuel of tomorrow from the residues of today. Trends Biotechnol 2006, 24(12):549-556.

4. Schubert C: Can biofuels finally take center stage? Nat Biotech 2006 24:777-784.

5. van Zyl WH, Lynd LR, den Haan R, McBride JE: Consolidated bioprocessing for bioethanol production using Saccharomyces cerevisiae. Adv Biochem Eng Biotechnol 2007, 108:205-235

6. Elkins JG, Raman B, Keller M: Engineered microbial systems for enhanced conversion of lignocellulosic biomass. Curr Opin Biotechnol 2010, 21(5):657-662.

7. Olofsson K, Bertilsson M, Lidén G: A short review on SSF - an interesting process option for ethanol production from lignocellulosic feedstocks. Biotechnol Biofuels 2008, 1(1):7.

8. Merino ST, Cherry J: Progress and challenges in enzyme development for biomass utilization. Adv Biochem Eng Biotechnol 2007, 108:95-120.

9. Van Vleet $\mathrm{JH}$, Jeffries TW: Yeast metabolic engineering for hemicellulosic ethanol production. Curr Opin Biotechnol 2009, 20(3):300-306.

10. Dellomonaco C, Fava F, Gonzalez R: The path to next generation biofuels: successes and challenges in the era of synthetic biology. Microb Cell Fact 2010, 9:3.

11. Weber C, Farwick A, Benisch F, Brat D, Dietz H, Subtil T, Boles E: Trends and challenges in the microbial production of lignocellulosic bioalcohol fuels. Appl Microbiol Biotechnol 2010, 87:1303-1315.

12. Long TM, Su YK, Headman J, Higbee A, Willis LB, Jeffries TW: Cofermentation of glucose, xylose and cellobiose by the beetle-associated yeast Spathaspora passalidarum. Appl Environ Microbio/ 2012, 78(16):5492-5500. 
13. Shaw AJ, Podkaminer KK, Desai SG, Bardsley JS, Rogers SR, Thorne PG, Hogsett DA, Lynd IR: Metabolic engineering of a thermophilic bacterium to produce ethanol at high yield. Proc Natl Acad Sci U S A 2008, 105:13769-13774.

14. Zhang B, Li L, Zhang J, Gao X, Wang D, Hong J: Improving ethanol and xylitol fermentation at elevated temperature through substitution of xylose reductase in Kluyveromyces marxianus. J Ind Microbiol Biotechnol 2013, 40(3-4):305-316.

15. Madeira-Lopes DA, Cabeça-Silva C: The dependence on temperature of thermal death, growth and yield of Candida tropicalis. J Basic Microbio 1984, 24(2):133-135

16. Ryabova $O B$, Chmil OM, Sibirny AA: Xylose and cellobiose fermentation to ethanol by the thermotolerant methylotrophic yeast Hansenula polymorpha. FEMS Yeast Res 2003, 4(2):157-164.

17. Suwannarangsee S, Oh DB, Seo JW, Kim CH, Rhee SK, Kang HA, Chulalaksananukul W, Kwon O: Characterization of alcohol dehydrogenase 1 of the thermotolerant methylotrophic yeast Hansenula polymorpha. Appl Microbiol Biotechnol 2010, 88(2):497-507.

18. Ishchuk OP, Voronovsky AY, Abbas CA, Sibirny AA: Construction of Hansenula polymorpha strains with improved thermotolerance. Biotechnol Bioeng 2009, 104(5):911-919.

19. Ishchuk OP, Abbas CA, Sibirny AA: Heterologous expression of Saccharomyces cerevisiae MPR1 gene confers tolerance to ethanol and L-azetidine-2-carboxylic acid in Hansenula polymorpha. J Ind Microbiol Biotechnol 2010, 37(2):213-218.

20. Gellisen $\mathrm{G}$ : Heterologous protein production in methylotrophic yeasts. Appl Microbiol Biotechnol 2000, 54:741-750.

21. Gellisen G: Hansenula polymorpha - biology and applications. Weinheim: Wiley VCH; 2002

22. Hansenula polymorpha Genome Database. [http://genome.jgi-psf.org/ Hanpo2/Hanpo2.home.html]

23. Voronovsky AY, Rohulya OV, Abbas CA, Sibirny AA: Development of strain of the thermotolerant yeast Hansenula polymorpha capable of alcoholic fermentation of starch and xylan. Metab Eng 2009, 11(4-5):234-242.

24. Voronovsky AY, Ryabova OB, Verba OV, Ishchuk OP, Dmytruk KV, Sibirny AA: Expression of $x y l A$ genes encoding xylose isomerases from Escherichia coli and Streptomyces coelicolor in the methylotrophic yeast Hansenula polymorpha. FEMS Yeast Res 2005, 5(11):1055-1062.

25. Dmytruk OV, Voronovsky AY, Abbas CA, Dmytruk KV, Ishchuk OP, Sibirny AA: Overexpression of bacterial xylose isomerase and yeast host xylulokinase improves xylose alcoholic fermentation in the thermotolerant yeast Hansenula polymorpha. FEMS Yeast Res 2008, 8(1):165-173.

26. Petschacher B, Nidetzky B: Engineering Candida tenuis Xylose reductase for improved utilization of NADH: antagonistic effects of multiple side chain replacements and performance of site-directed mutants under simulated in vivo conditions. App/ Environ Microbio/ 2005, 71(10):6390-6393.

27. Dmytruk OV, Dmytruk KV, Abbas CA, Voronovsky AY, Sibirny AA: Engineering of xylose reductase and overexpression of xylitol dehydrogenase and xylulokinase improves xylose alcoholic fermentation in the thermotolerant yeast Hansenula polymorpha. Microb Cell Fact 2008, 7:21.

28. Ishchuk OP, Voronovsky AY, Stasyk OV, Gayda GZ, Gonchar MV, Abbas CA, Sibirny AA: Overexpression of pyruvate decarboxylase in the yeast Hansenula polymorpha results in increased ethanol yield in hightemperature fermentation of xylose. FEMS Yeast Res 2008, 8(7):1164-1174

29. Ganapathy-Kanniappan S, Vali M, Kunjithapatham R, Buijs M, Syed LH, Rao PP, Ota S, Kwak BK, Loffroy R, Geschwind JF: 3-bromopyruvate: a new targeted antiglycolytic agent and a promise for cancer therapy. Curr Pharm Biotechnol 2010, 11(5):510-517.

30. Cardaci S, Rizza S, Filomeni G, Bernardini R, Bertocchi F, Mattei M, Paci M, Rotilio G, Ciriolo MR: Glutamine deprivation enhances antitumor activity of 3-bromopyruvate through the stabilization of monocarboxylate transporter-1. Cancer Res 2012, 72(17):4526-4536.

31. Shoshan MC: 3-Bromopyruvate: targets and outcomes. J Bioenerg Biomembr 2012, 44(1):7-15.

32. Sohn J, Choi E, Kang H, Rhee J, Agaphonov M, Ter-Avanesyan M, Rhee S: A dominant selection system designed for copy-number-controlled gene integration in Hansenula polymorpha DL-1. Appl Microbiol Biotechnol 1999, 51:800-807

33. Matsushika A, Sawayama S: Comparative study on a series of recombinant flocculent Saccharomyces cerevisiae strains with different expression levels of xylose reductase and xylulokinase. Enzyme Microb Technol 2011, 48:466-471.

34. Parachin NS, Bergdahl B, van Niel EWJ, Gorwa-Grauslund MF: Kinetic modelling reveals current limitations in the production of ethanol from xylose by recombinant Saccharomyces cerevisiae. Metab Eng 2011, 13:508-517.

35. Jeffries TW, Grigoriev IV, Grimwood J, Laplaza JM, Aerts A, Salamov A Schmutz J, Lindquist E, Dehal P, Shapiro H, Jin YS, Passoth V, Richardson PM: Genome sequence of the lignocellulose-bioconverting and xylosefermenting yeast Pichia stipitis. Nat Biotechnol 2007, 25(3):319-326.

36. Wang R, Li L, Zhang B, Gao X, Wang D, Hong J: Improved xylose fermentation of Kluyveromyces marxianus at elevated temperature through construction of a xylose isomerase pathway. J Ind Microbiol Biotechnol 2013, 40(8):841-854.

37. Sambrook J, Fritsh EF, Maniatis T: Molecular Cloning: A Laboratory Manual. Cold Spring Harbor: Cold Spring Harbor Press; 1989.

38. Faber KN, Haima P, Harder W, Veenhuis M, Ab G: Highly-efficient electrotransformation of the yeast Hansenula polymorpha. Curr Genet 1994, 25:305-310.

39. Postma E, Verduyn C, Scheffers WA, Van Dijken JP: Enzymic analysis of the crabtree effect in glucose-limited chemostat cultures of Saccharomyces cerevisiae. Appl Environ Microbiol 1989, 55:468-477.

40. Gonchar MV, Maidan MM, Sibirny AA: A new oxidase-peroxidase kit "Alcotest" for ethanol assays in alcoholic beverages. Food Technol Biotechnol 2001, 39:37-42.

doi:10.1186/s12934-014-0122-3

Cite this article as: Kurylenko et al:: Metabolic engineering and classical selection of the methylotrophic thermotolerant yeast Hansenula polymorpha for improvement of high-temperature xylose alcoholic fermentation. Microbial Cell Factories 2014 13:122

\section{Submit your next manuscript to BioMed Central and take full advantage of:}

- Convenient online submission

- Thorough peer review

- No space constraints or color figure charges

- Immediate publication on acceptance

- Inclusion in PubMed, CAS, Scopus and Google Scholar

- Research which is freely available for redistribution 